\title{
Tourism Village Management Requires Good Tourism Governance: Study in the Kampung Lampion Code 18 Yogyakarta
}

\author{
Galih W. Pradana \\ Department of Public Administration, Faculty of Social Sciences and Law \\ Unversitas Negeri Surabaya \\ galihpradana@unesa.ac.id \\ Amni Zarkasyi Rahman \\ Department of Public Administration, Faculty of Social and Political Sciences \\ Diponegoro University \\ amni.rahman@live.undip.ac.id \\ Hafids Haryonno \\ Department of Public Administration, Faculty of Social Sciences and Law \\ Universitas Negeri Surabaya \\ hafidz.haryono@gmail.com
}

\begin{abstract}
The objective of this research is to fully understand the use of the Good Tourism Governance principles in the management of the tourist villages of the Kampung Lampion Code 18 in Yogyakarta. There was a negative perception of settlements around the Code river, Yogyakarta. They were considered to cause river water pollution, narrowing of rivers, sedimentation and flooding. Then, the community changed that perception. Together with the Non-Governmental Organization the Center for Civic Engagement \& Studies and assisted by several university students, they turned the area into a tourist spot with the name Kampung Lampion Code 18. This is a qualitative research with descriptive method. Data analysis was applied at both the first step (data processing) and second step (interpretation). The study results indicate that the management of Kampung Lampion Code 18 has tried to apply the principles of good tourism governance. However, its implementation has not been effective. Stakeholder synergy has not been realized, training programs have not been sustainable, the benefits of tourism have not been widely felt, have not encouraged local ownership, and promotion is still minimal. The limitations of this study are that it relies heavily on the researcher's interpretation of the interview data; therefore, the possibility of bias persists. However, this study suggests the need for Good Tourism Governance Principles if the village wants to compete as an alternative tourism destination.
\end{abstract}

Keywords: good tourism governance, tourism village, and Kampung Lampion Code 18

\section{Good Tourism Governance dalam Pengelolaan Kampung Wisata: Studi pada Kampung Lampion Code 18, Yogyakarta}

\begin{abstract}
Abstrak
Penelitian ini bertujuan untuk memahami secara mendalam penerapan prinsip Good Tourism Governance dalam pengelolaan kampung wisata di kawasan Kampung Lampion Code 18 Kota Yogyakarta. Berawal dari keberadaan permukiman di sekitar sungai Code yang dianggap membawa dampak negative seperti pencemaran air sungai, penyempitan badan sungai, serta erosi, dan sedimentasi yang menyebabkan banjir. Kemudian, masyarakat sekitar sungai Code merubah persepsi tersebut. Bersama dengan Lembaga Swadaya Masyarakat Center for Civic
\end{abstract}

Corresponding author(s): Galih W. Pradana, Email: galihpradana@unesa.ac.id

Article history: Received, 29 September 2021; Revised, 13 November 2021; Accepted, 17 November 2021.

To cite this article: Pradana, G. W., Rahman, A. Z., \& Haryonno, H. (2021). Tourism Village Management Requires Good Tourism Governance: Study in the Kampung Lampion Code 18 Yogyakarta area. JPSI (Journal of Public Sector Innovations), 06(1), 20-27. https://doi.org/10.26740/jpsi.v6n1.p20-27 
Engagement \& Studies dan dibantu oleh beberapa mahasiswa dari berbagai perguruan tinggi, mengubah permukiman di bantaran sungai Code menjadi kawasan wisata dengan nama Kampung Lampion Code 18. Penelitian ini bersifat deskriptif dengan menggunakan pendekatan kualitatif. Analisis data dilakukan dua tahap baik analisis pada langkah permulaan (pengolahan) maupun langkah lanjut (penafsiran). Hasil penelitian menunjukkan bahwa prinsip good tourism governance dalam pengelolaan kampung wisata di kawasan Kampung Lampion Code 18 sudah diterapkan, namun penerapannya belum optimal. Hal tersebut terlihat dari sinergitas pemangku kepentingan belum sepenuhnya terwujud, program pelatihan belum berkelanjutan, manfaat wisata dan kemitraannya belum dirasakan secara luas, belum mendorong kepemilikan lokal, promosi masih minim dan berdiri sendiri-sendiri, serta pedoman monitoring dan evaluasi program masih sederhana. keterbatasan penelitian adalah subjektivitas peneliti. Studi ini sangat bergantung pada interpretasi peneliti tentang makna yang ditunjukkan dalam wawancara; oleh karena itu, kemungkinan bias tetap ada. Prinsip Good Tourism Governance tersebut perlu dioptimalkan apabila kampung wisata di kawasan Kampung Code Lampion 18 hendak dijadikan alternatif wisata yang berdaya saing.

Kata kunci: good tourism governance, kampung wisata, dan Kampung Lampion Code 18

\section{INTRODUCTION}

Rivers are a type of water resource that provides substantial advantages and plays an essential part in human life. The rivers of Yogyakarta's Special Region include the Oyo, Opak, Gadjahwong, Code, Winongo, Bedog, and Serang. Among the various rivers, the Code River has piqued the interest of many and is being controlled with haste. The Code River runs through Yogyakarta and is close to several significant places, including Malioboro, Tugu, Kraton, and others. The Code River flows through densely populated residential areas on both sides of the river, and its state deteriorates year after year.

Increased economic development activities, changes in land use, and population expansion have all harmed the watershed's ecosystem. With an everincreasing population growth rate, the Code River area has become a prime location for home construction. As a result, the issues in the Code River watershed have grown extremely complex. Starting with river water pollution, narrowing of the river body, significant erosion and sedimentation, and ending with floods in the Code River drainage basin. This is owing to the huge number of people of the communities along the Code River's banks, which should not be utilized as a residence. If this scenario persists, the river's function will be shifted into an uncontrolled region, resulting in social and economic issues in the environment. The flow coefficient analysis found that land conversion into builtup areas in Yogyakarta has an impact on water runoff. This has a significant impact on downstream. As one comes closer to the city, the density of the Code River area rises. Poverty and slums are two unfavorable outcomes of this scenario.

Aside from the negative impact of riverbank settlements, the Code River area has a lot of potential in the form of a strategic location in its orientation to other locations, environmental exoticism with the potential for ecotourism development, socio-cultural potential, and the attention of many parties. Throughout the region, several tiny villages have formed and are organized. Universities and government entities also conduct a variety of activities in the Code River area. The fundamental issue is that the associated parties have not been coordinated in a systematic manner, and the program layout is likewise not methodical.

When the 2030 Agenda and the United Nations Sustainable Development Goals (SDGs) were approved in 2015, it was unsurprising that tourism was designated as vital to progress toward the SDGs (Pasanchay \& Schott, 2021). Yogyakarta is a popular tourist destination, with the tagline "Yogyakarta Never Ending Asia." Peripheral regions with a low degree of primary sector diversification, such as agro-tourism, integration of processing and distribution activities, or quality production, are frequently defined by the exploitation of undeveloped areas' potential (Zasada \& Piorr, 2015). The Code River's unrepresentative status in sustaining Yogyakarta tourism need a concerted and long-term solution. Based on Water Resources Law No. 7 of 2004, the Serayu Opak Watershed Center created a Code River management and development strategy that focuses on five aspects: (1) conservation of water resources; (2) utilization of water resources; (3) controlling the destructive power of water; and (4) empowering and expanding the role of the community, private sector, and government.

One of the tourism items with the potential to be developed in Yogyakarta is the tourism village. Tourism village, as a new tourist destination with particular appeal based on the village area's potential, plays a significant role in enhancing people's welfare and boosting tourist visits (Dorojati \& Astuti, 2020: 73-86). Tourism villages may be one of the most important sectors in the tourism industry because they can encompass all forms of tourism with the character of the natural environment as the major attraction, such as wild nature tourism, adventure, natural scenery, culture, and animal husbandry, and so on (Hidayati et al., 2016).

The idea of governance in tourism destinations consists of creating rules and procedures for executing policies and economic plans that allow for the participation of all institutions and society masyarakat (Beritelli et al., 2007). The government has made several 
efforts to address different tourism-related issues, particularly those affecting the tourist community, by employing a variety of approaches or concepts. The government has frequently employed a variety of techniques, including Community Based Tourism, Sustainable Tourism, and Good Tourism Governance.

Good Tourist Governance is an adaption of the concept of Good Governance for tourism sector management. Based on this strategy, tourist sector management stresses the participation of three (three) key actors: the government, the community, and the corporate world (Sunaryo, 2013: 77). Because all three play a strategic role in tourist village management, the synergy of the three interactions is a factor that impacts the success of tourist village management, including tourist village management in the Kampung Lampion Code 18 region. The following are Cox's principles of good tourist management (Pitana \& Surya Diarta, 2009):

1) Tourism development and expansion must be founded on local wisdom and specific local sensitivities that represent the uniqueness of the cultural heritage and the uniqueness of the environment.

2) Preservation (maintenance), aegis (protection), and enhancing the quality of resources that serve as the foundation for the development of tourism destinations are all examples of preservation.

3) Development of new tourist attractions based on local cultural characteristics.

4) Tourism services focused on the uniqueness of the local culture and environment.

5) Support and legitimize tourism development and development if it is proven to provide positive benefits, but control and/or halt tourism activities if they exceed the carrying capacity of the natural environment or social acceptability, even if they have the potential to increase people's income (Pitana and Diarta, 2009:81).

Sunaryo went on to say that excellent tourist governance is comprised of 10 elements. Relevant community participation, stakeholder involvement, local ownership partnerships, resource sustainability, community aspirations, environmental carrying capacity, program monitoring and evaluation, environmental accountability, related community training, and publicity and advocacy of local cultural values are among these principles (Sunaryo, 2013: 7881). Several Good Tourism Governance ideas are applied to the challenges encountered in the management of tourist villages in Yogyakarta's Kampung Lampion Code 18 region (Sunaryo, 2013: 7881). The appropriateness comprises the following: (1) insufficient resource circumstances and weak village organization, which leads to the concept of resource sustainability; (2) a lack of public awareness, which includes the principle of community participation in relation to; (3) the availability of village facilities that do not support tourism, referring to the principle of environmental carrying capacity; and (4) a lack of tourism promotion; (5) the concept of local ownership partnerships includes less-than-optimal partnerships; and (6) the same with the weak superstructure.

According to this explanation, researchers are interested in doing study on Good Tourism Governance in the Management of Tourism Villages in the Yogyakarta City Kampung Lampion Code 18 region. The goal of this study is to acquire a complete knowledge of the use of Good Tourism Governance principles in the development of tourism villages in Yogyakarta's Kampung Lampion Code 18 region. The findings of this study are significant because they may offer an overview of tourist villages, as well as input and recommendations to all stakeholders, in order to create a tourist village in Kampung Lampion Code 18 and a tourist village in Yogyakarta City as the primary tourist attraction.

\section{METHODS}

This study falls under descriptive research using qualitative approach. This study was carried out in Yogyakarta's Kampung Code district, namely in the Kampung Lampion Code 18. The subjects of this study were the Secretary of the Kampung Lampion Code 18 and the surrounding neighborhood. Primary data was gathered through interviews and field observations. While secondary data is collected from document data received from the players involved in the study site, includes the village secretary, the neighborhood around the Kampung Lampion Code 18, and the Center for Civic Engagement and Studies. In this study, the researcher is the research instrument, aided by research aids such as paper, pencil, or ballpoint pen, interview instructions, observation guidelines, and mobile phones that act as recording devices and cameras. Understanding the study methodology as well as knowledge of tourism regions, tourist villages, and efficient tourism management are required for researcher validation.

The data collection approach is divided into several parts, namely: 1) semi-structured interviews, so that the flow of questions in the interview is more focused, clear, and easily understood by the informants encountered; 2) structured interviews, where the researchers made non-participatory observations, the observations were made by researchers by looking at the condition of the supporting facilities for the tourist village, the activity of the tourist village, and the utilization of various resources in the management of the tourist village in the Kampung Lampion Code 18; and 3) structured interviews, so that the flow of questions in the interview is more focused, clear, and easily 2) Observation, where the researchers did nonparticipatory observation by looking at the condition of the tourist village's supporting facilities, the activities of the tourist village, and the utilization of various resources in the Kampung Lampion Code 18 area; 3) documentation, research supporting materials in the form of pictures o In this study, the source triangulation technique is employed. 
Researchers attempted to compare observation data with interviews, one's position and point of view with the opinions and points of view of others, and the findings of interviews with the documentation's contents. . The data analysis approach applied examines both the first stage (processing) and the subsequent step (interpretation) (Pranowo 2012: 238-239). This qualitative research method consists of two stages of analysis: the first (processing) and the second (analysis) (interpretation).

\section{RESULTS AND DISCUSSION}

According to the findings of the researcher's interviews with Mr. Sugeng (Kampung Code Secretary) and Mr. Wasiman (Kampung Code), the original impetus for the establishment of Kampung Lampion Code 18 came from institutions and communities interested in Kampung Code. The institution is known as CCES (Center for Civic Engagement \& Studies). CCES is an organization that houses numerous communities, one of which being the Cemara community. The community challenges the residents of Ledok Code to build something that may be appreciated by a large number of people, so that it can subsequently attract tourists, both local and foreign tourists. Furthermore, this activity is sponsored by students from several institutions in Yogyakarta who are participating in community service program. The Kampung Lampion Code, like other tourist villages, suffers a number of challenges, including a lack of money, a lack of public knowledge of village management, a lack of tourist village organization or institutionalization, and inadequate village infrastructure. Supporting tourist activities, a lack of tourism marketing/promotion, and debt are all factors to consider. According to Mr. Sugeng, the community's potential is actually rather great in comparison to other rural communities, but it has yet to be realized. This is due to the fact that the neighborhood does not receive regular attention and inspiration from the local administration. Governance is defined by the World Tourism Organization as "a measurable practice of government aimed at effectively directing the tourism sector at various levels of government through efficient, transparent, and accountable forms of coordination, collaboration, and/or cooperation, which helps to achieve common goals of collective interest." shared by a network of sector actors with the goal of generating solutions and opportunities through agreements based on interdependence and shared responsibilities" (Durán, 2013).

The application of ten governance principles, which include stakeholder involvement, community participation, related community training, local ownership partnerships, sustainable use of resources, accommodating community aspirations, resource environmental support, environmental accountability, and tourism promotion and advocacy, can be used to measure the success of good tourism governance (Sunaryo, 2013:78-81). The following are ten criteria of effective tourism governance in the implementation of tourist villages in Yogyakarta's Kampung Lampion Code 18:

\section{Involvement of all Stakeholders}

Sunaryo (2013:78) contends that actors and stakeholders must actively and effectively engage in tourist development activities. In this scenario, the actors are all significant and interested parties who gain from tourism operations. Sunaryo's theoretical explanation is that stakeholders must be included in the entire process of managing tourist villages in Yogyakarta City's Kampung Lampion Code 18 region in order to achieve the aim of adopting efficient tourism governance. The concept of integrating all stakeholders in Good Tourism Governance (Sunaryo, 2013:78) has not been fully realized since stakeholders' actions and synergies have not been fully realized. Several factors have hampered the application of these principles thus far, including a lack of local government contributions, a lack of government communication with other actors, a lack of available funds to carry out optimal management, the presence of other tourism actors who have not been synergized, and a lack of active village tourism management organizations.

\begin{tabular}{|l|l|l|}
\hline \multicolumn{3}{|c}{ Table 1. Summary Criteria 1 } \\
\hline Criteria & \multicolumn{1}{|c|}{ Result } & $\begin{array}{c}\text { Keys } \\
\text { Constrai } \\
\text { ning }\end{array}$ \\
\hline \multicolumn{1}{|c|}{$(1)$} & \multicolumn{1}{|c|}{$(2)$} & $(3)$ \\
\hline $\begin{array}{l}\text { Involve- } \\
\text { ment of } \\
\text { all Stake- } \\
\text { holders }\end{array}$ & $\begin{array}{l}\text { The concept of integrating all } \\
\text { stakeholders in Good Tourism } \\
\text { Governance has not been fully } \\
\text { realized since stakeholders' } \\
\text { actions and synergies have not } \\
\text { been fully realized. }\end{array}$ & $\begin{array}{l}\text { Stake- } \\
\text { holders } \\
\text { actions }\end{array}$ \\
\hline
\end{tabular}

\section{Participation in Related Community Activities}

The community, according to (Sunaryo, 2013:78), must be active in overseeing or managing any existing tourist initiatives. Participation can range from developing a vision, purpose, or aim for tourism development to identifying potential tourist attractions and their development or management operations, as well as engaging in the execution of planned plans and programs. According to the researchers, community involvement in Kampung Wisata in Kampung Lampion Code 18 begins with the formation of a Tourism Village, program formulation and execution, and participation in overseeing the Tourism Village's operational administration. Furthermore, the application of these principles in the implementation of Tourism Villages in the Kampung Lampion Code 18 in accordance with the Yogyakarta Mayor Regulation Number 115 of 2015, which explains one of the technical requirements for Tourism Villages implementation, namely that it must be communitybased, in article 5. Overall, the Tourism Village in Kampung Lampion Code 18 is designed with community engagement in mind. However, there are still some issues with the application of these principles, specifically those related to tourism village activities that are only followed by certain community members, 
the local community is not fully included, the tourism village community is passive in participating, and the younger generation is also involved. Because of the low degree of work required, it is not highly engaged. Local tourist operations are overseen by the community.

Table 2. Summary Criteria 2

\begin{tabular}{|c|c|c|}
\hline Criteria & Result & $\begin{array}{c}\text { Keys } \\
\text { Constrai } \\
\text { ning }\end{array}$ \\
\hline (1) & (2) & (3) \\
\hline $\begin{array}{l}\text { Participa- } \\
\text { tion in } \\
\text { Related } \\
\text { Commu- } \\
\text { nity } \\
\text { Activities }\end{array}$ & $\begin{array}{l}\text { The Tourism Village in Kampung } \\
\text { Lampion Code } 18 \text { is designed } \\
\text { with community engagement in } \\
\text { mind. However, there are still } \\
\text { some issues with the application } \\
\text { of these principles. }\end{array}$ & $\begin{array}{l}\text { Commu- } \\
\text { nity } \\
\text { engage- } \\
\text { ment }\end{array}$ \\
\hline
\end{tabular}

\section{Community Training in Related Communities}

Sunaryo (2013:80) asserts that sustainable tourism development always necessitates the implementation of education and training programs to equip knowledge and skills, as well as increase the community's ability and capacity as a potential resource. The training should concentrate on topics related to determining the long-term feasibility of tourist development. Furthermore, Sunaryo (2013:80) stated that the existence of tourism-related community education and training programs may be utilized to evaluate the idea of training for linked communities in Good Tourism Governance. Overall, the existence of different tourism-related education and/or community training programs hosted in Tourism Villages in Yogyakarta City's Kampung Lampion Code 18 region has shown the concept of training for the connected community. CCES and community service program students collaborated to develop an education and training program in the tourist town of Kampung Lampion Code 18 so that people could produce lanterns that were unique to them. Meanwhile, the lanterns that have been set are created from environmentally friendly recycled materials such as paint cans, fans, plastic cups, and etc.

Table 3. Summary Criteria 3

\begin{tabular}{|l|l|l|}
\hline \multirow{2}{*}{ Criteria } & \multicolumn{1}{|c|}{ Table 3. Summary Criteria 3 } & \multicolumn{1}{|c|}{$\begin{array}{c}\text { Keys } \\
\text { Constrai } \\
\text { ning }\end{array}$} \\
\hline \multicolumn{1}{|c|}{$(1)$} & \multicolumn{1}{|c|}{$(2)$} & \multicolumn{1}{c|}{$(3)$} \\
\hline $\begin{array}{l}\text { Community } \\
\text { Training in } \\
\text { Related } \\
\text { Communities }\end{array}$ & $\begin{array}{l}\text { The existence of different } \\
\text { tourism-related education } \\
\text { and/or community training } \\
\text { programs hosted in Tourism } \\
\text { Villages in Yogyakarta City's } \\
\text { Kampung Lampion Code 18 } \\
\text { has shown the concept of } \\
\text { training for the connected } \\
\text { community. }\end{array}$ & $\begin{array}{l}\text { Comm- } \\
\text { unity } \\
\text { training } \\
\text { pro- } \\
\text { grams }\end{array}$ \\
& \\
\hline
\end{tabular}

\section{Partnership for Local Ownership}

Partnership is described as collaboration between the government, business, and society to achieve common goals. Tourism enterprises, according to Sunaryo (2013:78), must be developed and maintained in conjunction with the local community through a synergistic partnership model. According to Sunaryo (2013:78), the interaction between the private sector (business players) in the tourist industry and local communities should be developed in order to foster local ownership of these various enterprises. Partnerships in tourist management and joint efforts in the construction and maintenance of supporting infrastructure for tourism enterprises, according to Sunaryo, are indicators of the concept's success. Tourist Villages' numerous partnerships and collaborations with a variety of private parties or current tourism industry participants effectively demonstrate the concept of local ownership partnerships in developing Tourism Villages in Kampung Lampion Code 18. The private sector provides money or materials, like as paint, to the Lantern manufacturing. Although the use of these ideas in practice is far from perfect. This is due to the fact that the advantages or repercussions of the partnership have not been felt by the entire population of Kampung Wisata. The engagement is also still in the nature of Corporate Social Responsibility (CSR) in general, rather than specifically with the tourist community. This partnership has not been successful in fostering the establishment of local ownership of various tourismrelated businesses in Kampung Lampion Code 18.

Table 4. Summary Criteria 4

\begin{tabular}{|l|l|l|}
\hline $\begin{array}{c}\text { Criteri } \\
\text { a }\end{array}$ & \multicolumn{1}{|c|}{ Result } & $\begin{array}{c}\text { Keys } \\
\text { Constrai } \\
\text { ning }\end{array}$ \\
\hline \multicolumn{1}{|c|}{$(1)$} & \multicolumn{1}{|c|}{$(2)$} & \multicolumn{1}{|c|}{$(3)$} \\
\hline $\begin{array}{l}\text { Partner- } \\
\text { ship for }\end{array}$ & $\begin{array}{l}\text { Tourist Villages' numerous } \\
\text { partnerships and collaborations } \\
\begin{array}{l}\text { Local } \\
\text { Owner- } \\
\text { ship }\end{array}\end{array}$ & $\begin{array}{l}\text { Parther- } \\
\text { ship and } \\
\text { current tourism industry } \\
\text { participants effectively demonstrate } \\
\text { collabor- } \\
\text { ations } \\
\text { partnerships in developing Tourism } \\
\text { Villages in Kampung Lampion } \\
\text { Code 18. }\end{array}$ \\
\hline
\end{tabular}

\section{Resources Used in a Sustainable Manner}

Every development process must be steered to achieve the desired result while making the greatest use of available resources (Jubaedah et al., 2008:32). Tourism development must be able to utilise the required resources in a sustainable way, which means that its activities must not misuse nonrenewable resources. As a result of economic divergence, more and more lower level barriers are formed and strengthened as a result of globalization and marketization, influencing people's everyday lives more directly and eventually leading to different resource allocation and shifting status (Xu et al., 2018). Tourism development plans must be implemented in such a way that the resources used may be saved and enhanced (Sunaryo, 2013:79). According to the study's findings, the use of resources in the Kampung Lampion Code 18 region for the implementation of village tourism includes the use of human resources, natural resources, cultural resources, special interest resources, and capital resources. 
This is consistent with Pitana and Diarta (2009:68) definition of tourist resources as "everything that has the potential to be developed directly or indirectly to benefit tourism." Furthermore, Pitana and Diarta (2009:68) note that natural resources, cultural resources, community resources, and special interest resources are commonly used in tourist development. Overall, village tourism in Kampung Lampion Code 18 has met the principle of sustainable resource use. This is seen in how Kampung Code employs diverse resources without jeopardizing sustainability concerns, such as the utilization of natural, human, cultural, and special interests resources, as well as capital resources. The use of natural resources that are not excessive and the growth of the tourist industry are regarded not to harm the environment and the natural beauty generated by utilizing old products to make lanterns that are more ecologically friendly may be seen as resource usage here. These obstacles are mostly connected to internal human resource issues within the village tourist organization, limited funding for the tourism village, and the exploitation of scattered cultural treasures. The money for manufacturing the lanterns was provided by the NGO CCES in the sum of Rp. 400,000 in order for Kampung Lampion Code 18 to become a new tourist destination in Yogyakarta.

Table 5. Summary Criteria 5

\begin{tabular}{|l|l|l|}
\hline Criteria & \multicolumn{1}{|c|}{ Result } & \multicolumn{1}{|c|}{$\begin{array}{c}\text { Keys } \\
\text { Constrai- } \\
\text { ning }\end{array}$} \\
\hline \multicolumn{1}{|c|}{$(1)$} & \multicolumn{1}{|c}{$(2)$} & \multicolumn{1}{c|}{$(3)$} \\
\hline $\begin{array}{l}\text { Resources } \\
\begin{array}{l}\text { Used in a } \\
\text { Sustainable } \\
\text { Manner }\end{array}\end{array}$ & $\begin{array}{l}\text { The idea of sustainable resource } \\
\text { usage has been satisfied through } \\
\text { village tourism in Kampung } \\
\text { Lampion Code 18. }\end{array}$ & $\begin{array}{l}\text { Sustaina- } \\
\text { ble } \\
\text { resource } \\
\text { use }\end{array}$ \\
\hline
\end{tabular}

\section{Accommodating Community Aspiration}

The aspirations and goals of local communities must be incorporated into the tourist activity plan in order to successfully establish a harmonic state between each of the tourism components involved, beginning with the planning, management, and marketing phases (Sunaryo, 2013:79). According to this view, the notion of accommodating people's aspirations may be assessed by the presence or absence of attempts to accommodate, channel, and follow up on community aspirations. It may also exacerbate the need to respond effectively to the sector's difficulties and players' expectations, as well as the rising public desire for greater openness (Bono $i$ Gispert \& Anton Clavé, 2020). In accordance with this concept, attempts have been undertaken to establish a tourism village in the Kampung Lampion Code 18 region to house, distribute, and monitor the community's village tourism aspirations. It was obvious that the concept for a lampion (lanterns) village came from the inhabitants. People send ideas to CCES, locals speak and collaborate, and people provide ideas for constructing community lanterns at the end of the year to improve the village's position so that a visit to CCES is worthwhile. So, with the presentation, CCES finally provided locals with cash for the production of these lanterns.

\begin{tabular}{|c|c|c|}
\hline Criteria & Result & $\begin{array}{c}\text { Keys } \\
\text { Constra- } \\
\text { ining } \\
\end{array}$ \\
\hline (1) & (2) & (3) \\
\hline $\begin{array}{l}\text { Accommo- } \\
\text { dating } \\
\text { Commu- } \\
\text { nity } \\
\text { Aspiration }\end{array}$ & $\begin{array}{l}\text { The notion of accommodating } \\
\text { people's aspirations has been } \\
\text { undertaken to establish a } \\
\text { tourism village in the Kampung } \\
\text { Lampion Code } 18 \text { region. }\end{array}$ & $\begin{array}{l}\text { Commu- } \\
\text { nity } \\
\text { aspira- } \\
\text { tions }\end{array}$ \\
\hline
\end{tabular}

\section{Environmental Carrying Capacity}

Sunaryo (2013:79) highlights that in order to provide a range of tourism facilities and activities, the carrying capacity of the environment, including physical, biotic, socioeconomic, and cultural carrying capacity, must be the primary focus in successful tourism management. According to Sunaryo (2013:79), development and expansion must be reasonable and in line with local capacity limits and present environmental carrying capacity. In tourist communities in the Kampung Lampion Code 18 region, the concept of environmental carrying capacity has not been realized. This is due to the fact that river water cannot be used for daily use. Toilet waste is dumped into the river by Code River neighborhoods. The majority of Code River communities do not have their own bathrooms. As a result, there are several public restrooms whose water originates from wells purposefully dug by the local community.

\begin{tabular}{|l|l|c|}
\multicolumn{1}{l}{ Table 7. Summary Criteria 7 } \\
\hline \multicolumn{1}{|c|}{ Criteria } & \multicolumn{1}{|c|}{ Result } & $\begin{array}{c}\text { Keys } \\
\text { Constrai- } \\
\text { ning }\end{array}$ \\
\hline $\begin{array}{l}\text { Environ- } \\
\text { mental }\end{array}$ & $\begin{array}{l}\text { The concept of environmental } \\
\text { carrying capacity has not been } \\
\text { realized. This is due to the fact } \\
\text { Carrying } \\
\text { Capacity } \\
\text { that river water cannot be used } \\
\text { for daily use. }\end{array}$ & $\begin{array}{l}\text { River } \\
\text { water }\end{array}$ \\
\hline
\end{tabular}

\section{Environmental Accountability}

According to Sunaryo (2013:80), the design of tourist development programs must constantly include the possibilities of finding job, boosting income, and improving the health of the local population, as evidenced by existing tourism development policies, programs, and strategies. Natural resource management and utilization, such as land, water, and air, must assure high performance accountability while preventing overexploitation of current resources. Environmental accountability may be assessed by determining whether or not there are advantages to the community environment (social, economic, and cultural) as well as the use of resources that assure environmental sustainability (nature). Without being overutilized overall, these ideas have performed admirably. This is evidenced by the community's active engagement in the construction of the Kampung Lampion Code 18. The 
local community does everything from raising finances to constructing lanterns to caring for and maintaining them. So that the Kampung Lampion Code 18 can stay viable by providing chances for the community to be creative. Because of the presence of Kampung Lampion Code 18 as a tourist village, the community is aware of the need of participating in the maintenance and care of their village by constantly keeping the surroundings clean. The Kampung Lampion Code 18 has a beneficial influence in that it keeps the Code 18 River Area clean and comfortable to live in.

Table 8. Summary Criteria 8

\begin{tabular}{|l|l|l|}
\hline Criteria & \multicolumn{1}{|c|}{ Result } & $\begin{array}{c}\text { Keys } \\
\text { Constrai- } \\
\text { ning }\end{array}$ \\
\hline \multicolumn{1}{|c|}{$(1)$} & \multicolumn{1}{|c|}{$(2)$} & $(3)$ \\
\hline $\begin{array}{l}\text { Environ- } \\
\text { mental } \\
\text { Accounta- } \\
\text { bility }\end{array}$ & $\begin{array}{l}\text { The local community } \\
\text { undertakes everything from } \\
\text { raising funds to building } \\
\text { lanterns to caring for and } \\
\text { maintaining them, as well as } \\
\text { contributing to the upkeep and } \\
\text { care of their village. }\end{array}$ & $\begin{array}{l}\text { Mainte- } \\
\text { nance }\end{array}$ \\
\hline
\end{tabular}

\section{Local Cultural Values Promotion and Advocacy}

Tourism is frequently utilized as an alternate option, whether in industrialized or developing nations, to preserve long-term economic development in distant locations or villages where the primary traditional industries are practiced (Ying \& Zhou, 2007). According to Sunaryo (2013:80), sustainable tourism development also necessitates land use promotion and advocacy programs and activities that correctly portray the character of the area (sense of place) as well as the local population's cultural identity. The existence or absence of tourist marketing that promotes the character of the site, community values, and local cultural identity may be used to evaluate the principles of local culture promotion and advocacy. The concept of promoting and fighting for local cultural values has yet to be completely realized. The notion of cultural value promotion and advocacy has not been adequately applied. The application of principles in the implementation of Kampung Lampion Code 18 is still limited by existing but limited promotional efforts, promotional media such as websites that are not yet optimal, and limited collaboration with the private sector or local tourism actors in terms of joint promotion efforts. Instagram is the sole social media platform used for promotion.

Table 9. Summary Criteria 9

\begin{tabular}{|c|c|c|}
\hline Criteria & Result & $\begin{array}{c}\text { Keys } \\
\text { Constrai- } \\
\text { ning }\end{array}$ \\
\hline (1) & (2) & (3) \\
\hline $\begin{array}{l}\text { Local } \\
\text { Cultural } \\
\text { Values } \\
\text { Promotion } \\
\text { and } \\
\text { Advocacy }\end{array}$ & $\begin{array}{l}\text { The concept of promoting and } \\
\text { fighting for local cultural values } \\
\text { has yet to be completely realized, } \\
\text { it still limited by existing but } \\
\text { limited promotional efforts. }\end{array}$ & $\begin{array}{l}\text { Promo- } \\
\text { tional } \\
\text { media }\end{array}$ \\
\hline
\end{tabular}

\section{Monitoring and Evaluation of Programs}

Program monitoring and evaluation are two connected responsibilities in the framework of program control. Monitoring and evaluation activities in good tourism governance programs, according to Sunaryo (2013:80), range from developing guidelines to developing indicators or limits in measuring the implementation of monitoring and evaluation of activities as a whole to evaluating the impact of tourism activities. Monitoring and evaluating tourist programs, program monitoring and evaluation standards, and restrictions or indicators for assessing the impact of tourism activities, according to the researcher's view, are evidence of attaining this idea.

The achievement of the monitoring and evaluation program idea in the implementation of village tourism in Kampung Lampion Code 18 is adjusted to the theory of Good Tourism Governance, which is still regarded not optimal. Several parties collaborate to monitor and analyze the development of tourism villages based on fundamental criteria. This is consistent with the findings of Ardianto's (2016:73) research, which also indicated that the government is attempting to evaluate and monitor tourist activity programs. In practice, however, the growth of tourism communities has not been adequately monitored and evaluated. These principles are solely followed by the NGO Cemara, which continuously provides financial support for the upkeep of the Kampung Lampion Code 18. The absence of government engagement in overseeing the execution of village tourism is not specifically targeted to each village, but it is nevertheless carried out in general.

Table 10. Summary Criteria 10

\begin{tabular}{|l|l|l|}
\hline Criteria & \multicolumn{1}{|c|}{ Result } & \multicolumn{1}{|c|}{$\begin{array}{c}\text { Keys } \\
\text { Constrai- } \\
\text { ning }\end{array}$} \\
\hline \multicolumn{1}{|c|}{$(1)$} & \multicolumn{1}{|c|}{$(2)$} & \multicolumn{1}{c|}{$(3)$} \\
\hline $\begin{array}{l}\text { Moni-toring } \\
\text { and Evalua- } \\
\text { tion of } \\
\text { Programs }\end{array}$ & $\begin{array}{l}\text { The growth of tourism } \\
\text { communities has not been } \\
\text { adequately monitored and } \\
\text { evaluated. }\end{array}$ & $\begin{array}{l}\text { Govern- } \\
\text { ment } \\
\text { engage- } \\
\text { ment }\end{array}$ \\
\hline
\end{tabular}

\section{CONCLUSION}

The tourist village in Kampung Lampion Code 18 is being evaluated using Good Tourism Governance principles such as stakeholder involvement, related community participation, related community training, local ownership partnerships, sustainable use of resources, community aspirations, environmental carrying capacity, environmental accountability, and promotion. The accomplishments of each of these concepts have not been completely realized due to a variety of factors impeding their application. These issues might include a lack of participation from stakeholders that has not been completely realized, just select communities actively engaging, the training program being unsustainable owing to a lack of a regular training program schedule, and no follow-up. Creating training on how to make lanterns as well as 
training on how to create tourist settlements. The benefits of village tourism and its partnerships have not been widely felt and have not been able to encourage local ownership; promotions continue to be minimal and independent; and guidelines for monitoring and evaluating tourist villages remain simple, with no specific indicators to measure the impact of tourism activities carried out. If the tourist village in Kampung Lampion Code 18 is to be used as a superior and competitive tourist option, then the use of Good Tourism Governance principles must be improved.

Researchers can provide the following suggestions:

1) The Tourism Office must develop more precise and binding criteria or indicators for measuring tourist communities, as well as construct education and training programs that are more focused and customized to the community's requirements.

2) Local governments must oversee the establishment of tourist villages in Kampung Lampion Code 18 and encourage efforts to bring together tourism players who have never worked with tourist villages before.

3) It is required to enhance, regenerate, and reactivate the tourism village management organization, as well as to build a website as a promotional medium and source of information about tourist villages, as well as to produce more creative and original village tourism packages.

\section{REFERENCES}

Ardianto. (2016). Peran Dinas Pariwisata dalam Mengembangkan Potensi Wisata di Kabupaten Natuna. Skripsi. Yogyakarta: Universitas Muhammadiyah Yogyakarta.

Beritelli, P., Bieger, T., \& Laesser, C. (2007). Destination governance: Using corporate governance theories as a foundation for effective destination management. Journal of Travel Research, 46(1), 96-107. https://doi.org/10.1177/0047287507302385

Bono i Gispert, O., \& Anton Clavé, S. (2020). Dimensions and models of tourism governance in a tourism system: The experience of Catalonia. Journal of Destination Marketing and Management, 17(July). https://doi.org/10.1016/j.jdmm.2020.100465.

Dinas Pariwisata dan Kebudayaan DIY. (2021). Buku Statistik Kepariwisataan DIY 2014. Diunduh pada hari Senin, 6 September 2021 melalui situs https://visitingjogja.com/download/statistikpariwisata/.

Durán, C. (2013). Governance for the tourism sector and its measurement. UNWTO Statistics and TSA. Issue Paper $\quad$ Series, $1-34$. http://cf.cdn.unwto.org/sites/all/files/IP_Governan ce_paper_EN.pdf

Hidayati, R., Sudaryono, Wijono, D., \& Prayitno, B. (2016). Tourism Development of Historical Riverbanks in Jatinom Village. Procedia - Social and Behavioral Sciences, 227(November 2015), 650-655.

https://doi.org/10.1016/j.sbspro.2016.06.128

Jubaedah, E., Lili, N., \& Faozan, H. (2008). Model Pengukuran Pelaksanaan Good Governance di Pemerintah Daerah Kabupaten/Kota. 115.

Samsu, S. (2016). Metode Penelitian Kualitatif dalam Perspektif Rancangan. Jurnal Fokus Konseling, 2(2), 144-159.Peraturan Walikota Yogyakarta Nomor 115 Tahun 2016 tentang Penyelenggaraan Kampung Wisata.

Pasanchay, K., \& Schott, C. (2021). Community-based tourism homestays' capacity to advance the Sustainable Development Goals: A holistic sustainable livelihood perspective. Tourism Management Perspectives, 37(November 2020), 100784.

https://doi.org/10.1016/j.tmp.2020.100784

Pitana, I. G., \& Surya Diarta, I. K. (2009). Pengantar Ilmu Pariwisata. Penerbit Andi.

Prastowo, A. (2012). Metode Penelitian Kualitatif dalam Rancangan Penelitian. Yogyakarta: Ar-Ruzz Media.

Putri, W. D. (12 Januari 2017). Yogyakarta Terbitkan Aturan tentang Kampung Wisata. Diakses dihari Rabu, 8 September 2021 pada situs https://www.republika.co.id/berita/nasional/daerah /17/01/12/ojo1y7359-yogyakarta-terbitkan-aturantentang-kampung-wisata

Rini Dorojati, I. ,M. S. (2020). Peer Review "Model Pengorganisasian Masyarakat dalam Pengelolaan dan Pengembangan Kampung Wisata Prenggan Kecamatan Kotagede, Kota Yogyakarta."

Samsu, S. (2016). Metode Penelitian Kualitatif dalam Perspektif Rancangan. Jurnal Fokus Konseling, 2(2), 144-159.

Sunaryo, B. (2013). Kebijakan Pembangunan Destinasi.pdf (p. xiv + 240).

Undang-undang Republik Indonesia Nomor 10 tahun 2009 tentang Kepariwisataan

Xu, H., Huang, X., \& Zhang, Q. (2018). Tourism development and local borders in ancient villages in China. Journal of Destination Marketing and Management, 9(July 2017), 330-339. https://doi.org/10.1016/j.jdmm.2018.03.007

Ying, T., \& Zhou, Y. (2007). Community, governments and external capitals in China's rural cultural tourism: A comparative study of two adjacent villages. Tourism Management, 28(1), 96-107. https://doi.org/10.1016/j.tourman.2005.12.025

Yoeti, O. A. (1996). Pengantar Ilmu Pariwisata (p. 348).

Zasada, I., \& Piorr, A. (2015). The role of local framework conditions for the adoption of rural development policy: An example of diversification, tourism development and village renewal in Brandenburg, Germany. Ecological Indicators, 59, 82-93. https://doi.org/10.1016/j.ecolind.2015.02.002 